\title{
MYTHOLOGEM OF ODYSSEUS TRAVELS IN NOSTALGIC DISCOURSE OF POET-EMIGRANT ALEXANDRA PETROVA
}

\author{
МИФОЛОГЕМА ОДИССЕВЫХ СТРАНСТВИЙ \\ В НОСТАЛЬГИЧЕСКОМ ДИСКУРСЕ \\ ПОЭТА-ЭМИГРАНТА АЛЕКСАНДРЫ ПЕТРОВОЙ
}

\section{Svetlana Fokina ${ }^{1}$}

DOI: https://doi.org/10.30525/978-9934-588-38-9-39

\begin{abstract}
The subject of the study is the phenomenon of nostalgia as a cultural and emotional complex that causes the specificity of the emigrant's literary consciousness. The methodology of the study is due to the expediency of the goal and the solution of the above-mentioned tasks, which indicate the need to apply a systemic approach, including the interaction of elements of motivational, conceptual, semiotic and discourse analysis, the method of interpretation, as well as the connection of biographical and contextual approaches. The purpose of the article is to understand the interpretation of the phenomenon of nostalgia by the author's consciousness of the immigrant poet A. Petrova. The archetypal components of nostalgia and the supposed paradigm of nostalgic behavior and worldview have been identified. The question of continuity has been raised in the semiotic plan of the status of a traveler and an immigrant experiencing nostalgia. The mutual condition is emphasized of nostalgia and melancholia. In nostalgic discourse has been clarified the function of «passion semiotics» codes. The phenomenon of nostalgia been traced in the landmark lyrical plot of the modern poet-emigrant Alexandra Petroava. Artistic priorities are outlined of creative thinking of A. Petrova as a poet-immigrant and the transgressive specificity is attested of her poetic consciousness. The specificity of allusion has been clarified of the poem «On the Witchcraft Island Brood...». The influence is justified on the author's myth of A. Petrova of the place of her emigration - Italy. Artistic factors were analyzed among them the specifics of
\end{abstract}

\footnotetext{
${ }^{1}$ Candidate of Philological Sciences,

Associate Professor at Department of World Literature, Doctoral Candidate,

Odessa I.I. Mechnikov National University, Ukraine
} 
the Odysseus myth, its connection with the «island story», with behavioural strategies of «homo viator» and calyptic poetics. The role of mythological, semiotic and gender codes is emphasized in modeling the lyrical plot, as well as the process of identifying the lyrical self. The factors of manifestation are understood of confessional and ambivalence in the act of experiencing nostalgia. The ambivalence in the author's myth of A. Petrova manifests itself in different directions. In the form of an interchange in beating of femenine and maskulin codes the boundaries of consciousness. The transformation is indicative of the close myth as the acquisition of the alter «ego» - «wordbrother». It is of interest to activate the poetics of masks in the poetic discourse of A. Petrova. Significant literary masks (Odysseus, Calypso, Circe) have been identified in the act of identifying the lyrical «self».

\section{1. Введение}

Актуальность избранного ракурса исследования мотивирована несомненным интересом современного литературоведения к интенциям творческого сознания поэтов-эмигрантов и взаимосвязанному с ними феномену ностальгии.

Изученность феномена ностальгии уже имеет свои зарождающиеся традиции на стыке филологических и культурологических подходов. В данной связи стоит вспомнить раздел, посвященный ностальгии в монографии Ж. Старобинского «Чернила меланхолии» [см. 20] и научные поиски С. Бойм, в частности ее масштабное исследование «Будущее ностальгии» [см. 3]. Зарубежные ученные устремлены к осмыслению, прежде всего, истоков ностальгии как эмоционально-смыслового комплекса. В качестве материала для своих изысканий и иллюстрации идей избирают авторов либо ставших давно классиками (Овидий, Ш. Бодлер, А. Бергсон, В. Набоков и др.), либо обретающих этот статус в сегодняшней литературной ситуации (И. Бродский, И. Кабаков). Новаторским представляется изучение феномена ностальгии в лирике современного поэта-эмигранта Александры Петровой, чье творчество начинает получать отклик в критике, но заслуживает более последовательного и пристального внимания.

Цель статьи осмыслить интерпретацию феномена ностальгии авторским сознанием поэта-эмигранта А. Петровой. Задачи: 1) проанализировать специфику сознания поэта-эмигранта в соответствии с 
установками авторского мифа; 2) выявить доминанты ностальгического дискурса; 3) на материале стихотворения А. Петровой «По колдовскому острову брожу...» осмыслить своеобразие авторской рецепции одисеева мифа.

Методология исследования обусловлена целесообразностью реализации поставленной цели и решения указанных задач, что указывают на необходимость применения системного подхода, включающего взаимодействие элементов мотивного, концептуального, семиотического и дискурс-анализа, метода интерпретации, а также подключения биографического и контекстуального подходов.

Логика исследования мотивирована постановкой и попыткой решения проблемы актуализации ностальгии в поэтическом сознании эмигранта. В качестве опорной основы научного поиска был сформирован категориальный аппарат, включающий следующие понятия: лирическое «я», поэтическое сознание, авторский миф, ностальгия, «homo viator», одиссеев миф, островной сюжет, поэт-эмигрант. В соответствии с даными предпосылками предлагается следующая гипотеза. Трансгресивнисть сознания современных русских поэтов-эмигрантов кореллирует с ностальгическим дискурсом, что осусловливает своеобразие авторского мировосприятия и моделирование лирического сюжета.

\section{2. Своеобразие авторской позиции А. Петровой как поэта-эмигранта}

В третьей книге стихов «Только деревья» Александра Петрова фиксирует смену места эмиграции, ранее это был Иерусалим. Будучи ярким представителем современной русской поэтической диаспоры А. Петрова в новой книге обыгрывает некоторые римские топосы, вводит рецепции итальянских вех и образа жизни. По слову С. Сандлер, в третьей книге стихов А. Петровой «стихи путешествуют по Риму, то мысленно выгораживая площадку для культурно-исторических разысканий, то минуя безымянные поля и перелески» [17, с. 6]. Но более примечательно в поэтическом даровании А. Петровой обращение к феномену ностальгии, что может способствовать выявлению скрытых авторских кодов.

Дух современности отличает урбанистичность жизни человека, сформированная еще на этапе зарождающейся модерной модальности, ощущение пограничности существования и утраты ориентиров, 
присущее переходным эпохам. С точки зрения Н. Сподарец, для типа модернистского сознания «концепт трансгрессия стал базовым», включая в ментальную парадигму образ «человека в поисках своей идентичности» [19, с. 231]. Трансгрессивность, ироничность и даже разочарованность постпостмодерного мировидения нашего времени нуждаются в обретении хотя бы временной стабильности, уравновешивающей человеческое бытие.

Для авторского мифа Александры Петровой показателен феномен идентификации при сознательной установке на ее неосуществимость, как в рамках пола, так и в плане объекта ностальгии и поиска своего истинного «я». По мысли П. Рикёра, «повествование создает идентичность персонажа, которую мы можем назвать его нарративной идентичностью, строя идентичность рассказанной истории» $[15$, с. 180]. Обыгрываемые поэтессой трансгрессивность гендерных, социальных и автометаописательных ролей и пороговость сознания, активируемая ностальгическим дискурсом, в совокупности направлены на отражение противоречивой, во многом амбивалентной природы современного поэта-эмигранта, живущего во времена переходной эпохи. Отказ А. Петровой от идентификации показателен для различных пограничных феноменов, трансгрессивность которых определяет их противоречивую и во многом даже парадоксальную сущность. По наблюдению Н. Хренова, «изменчивость вещей в историческом времени мешает их идентифицировать» [24, с. 232], а присущее переходным эпохам и типам сознания стремление к ментальному отстранению от «исторического времени с его текучестью, изменчивостью и непредсказуемостью одновременно означает актуализацию мифологического времени как основу актуализации архетипов» [24, с. 233]. Для лирического дискурса А. Петровой показательна высокая степень архетипичности, что соответствует ее стремлению включать в свой авторский миф мифологемы двойничества, близнечности, метаморфоз и трансформаций как макрокосма - мира вокруг, так и микрокосма - образа лирического «я».

Несомненна преемственность лирического дискурса А. Петровой традициям русской и европейской лирики, что было верно подчеркнуто Стефани Сандлер. В рецензии на книгу стихов «Только деревья» (2007), примечательно названной «Поэт как перемещенное лицо», отмечена определенная тенденция творчества А. Петровой. С. Санд- 
лер утверждает, «...поэт укореняется в итальянской жизни, но всё с той же силой ощущает свою вечную непривязанность» $[17$, с. 6]. Данный ракурс акцентирует особое мировосприятие присущее А. Петровой как поэту-эмигранту: установку авторского сознания на утрату ощущения укоренности где бы то ни было и потенциальный разрыв социальных, этнических, культурных и личностных связей. Но, в то же время, именно такая позиция, чтобы не стать тотальной и трагической нуждается в поиске путей стабилизации психосферы личности.

Название третьего стихотворного сборника А. Петровой «Только деревья» задает темы природы, экологии и обыгрывает образ мирового древа. Наблюдения Я. С. Линьковой подтверждают, что в современной литературной ситуации актуальность расширения «сферы влияния и функций современной пасторали путем включения в художественный текст концепций эколитературы» делает «этот жанр открытым всем новейшим трактовкам поэтики...» [8, с. 273]. Осознание несомненной важности сегодня эколитературы вполне могло стимулировать интеpec A. Петровой и имплицитно активизировать механизмы самостабилизации. В контексте взаимосвязи эколитературы и пасторальности Н. Пахсарьян отмечает явное стремление эстетико-философского универсума «противостоять прогрессирующему разрушению естественного ландшафта» $[11$, с. 174]. Но представляется более убедительной версия потребности поэтессы найти эквивалент вдохновения, обретения подлинности и познания себя, которые в сознании А. Петровой нерасторжимо связаны с природой. Помимо внимания к теме экологии, проявлено стремление раскрыть архетипические коннотации пастушьей роли, неоднократно мифологически приписываемой поэту. По наблюдениям Л. Бугаевой, «писатель-эмигрант, лишенный корней и вынужденный приспосабливаться к их отсутствию, рассматривает писание не только как возможность формирования жизненного пространства, но и как возможность авторефлексии и конструирования или реконструирования “я" после пережитой травмы эмиграции» [4, с. 203]. Затрудненность идентификации личности поэта-эмигранта в современном мире компенсируется авторефлексивностью сознания. В случае А. Петровой подобная авторефлективность представляется повышенной, а тема деревьев задает образ корней, что значимо для поэта-эмигранта и становится одним из кодов ностальгирования. 
В образе деревьев прочитывается также интертекстуальная отсылка непосредственно к циклу М. Цветаевой «Деревья», а шире - диалог со всем цветаевским творчеством. Как известно, тема деревьев была важна и излюблена М. Цветаевой. Цветаевский интерес к природе эксплицировал не только приоритеты художественной идеологии, но и свидетельствовал о важных изменениях мировосприятия художником слова и человеком. Так по убежденности И. Шевеленко, в период создания цикла «Деревья» (1922) для М. Цветаевой «единственным достойным “другим" < .. > является природа. < ..> Природа - воплощение мира бессмертья на земле, творение той же силы, что руководит и поэтом. Потому для поэта именно в природе лежит истинный и исконный оплот, вечное обещание духовной защиты» [27, с. 243]. В подтверждение высказанной мысли исследовательница приводит цветаевское стихотворение «В смертных изуверясь...», в котором помимо излюбленных тем и мотивов М. Цветаевой: сиротства, одиночества, устремленности ввысь, обыгрываются смысловые комплексы разочарованности в людях, невозможности любви («Зачароваться не тщусь»), ощущения родства и духовного единства с природой («Ввысь, где рябина / Краше Давида-Цаpя! / В вереск-седины, / В вереск сухие моря!»). Не менее показательно известное цветаевское высказывание: «В чем же отличие произведения искусства от произведения природы, поэмы от дерева? Ни в чем» $[25$, с. 24]. Такой интертекстуальный подстрочник способствует рассмотрению заглавного образа третьей поэтической книги А. Петровой как осуществления диалога не только с природой, но и наследием М. Цветаевой. Интерес А. Петровой к метатеме природы и в соответствии с этим, не в меньшей степени, пасторальности, становится не только показателем современной усталости жителя мегаполиса, но и знаком переосмысления цветаевской традиции. Для А. Петровой показательно стремление соотносить творческие искания с природными мотивами, что на уровне подтекста можно прочитывать как маркер ностальгии.

\section{3. Пассионарный характер ностальгии}

Несомненной представляется взаимосвязь ностальгического чувства с миром страстей, определяющих своеобразие мировосприятия, переживающего их субъекта. К. Юханнисон прослеживает традиции рассмотрения ностальгии как одной из «болезней страстей» наравне с 
эротоманий, бешенством и т. д. Шведская исследовательница отмечает, что ностальгия одно из проявлений меланхолии, имеющей «пограничный характер и <..> представляет собой древнюю форму психического страдания...» [28, с. 20]. Ностальгик своей фантазией моделирует особую психическую реальность, балансирующую между острой тоской по утраченному, несбыточному и возможностью с помощью воображения преодолеть любые границы. Показательно выстраивание А. Петровой лирического сюжета как взгляда на мир через призму ностальгии. Ностальгирование лирического «я» позволяет расширить рамки своей идентификации, как с помощью обращения к одисеевской теме, так и воссоздавая своего рода исповедь.

С точки зрения А. Ж. Греймаса и Ж. Фонтания, «страсть обеспечивает присутствие $<\ldots>$ некоторого набора данных, одновременно напряженных и фигуративных, как, например, это происходит в случае ностальгии о ситуации, которая была или могла бы быть...» [5, с. 70]. В рамках лирического сюжета А. Петровой такой ситуацией становится представление о гипотетическом возвращении домой, которое, трансформируя канон одисеева мифа, оказывается для лирического «я» сознательно недостижимым. Потенциальная амбивалентность ностальгического чувства, тоски как о том, что было, так и о том, что можно вообразить и желать, открывает широкий спектр интерпретации ностальгических проявлений. Авторы «Семиотики страстей» отмечают обеспечиваемое страстным дискурсом противоречие, возникающее между «крупными тенденциями человеческого воображения, ожиданием и ностальгией» [5, с. 287]. Несомненная связь ностальгии со сферой воображения задает некую альтернативу для ностальгика: меланхолического переживания утраченного или же устремления к не осуществленному, но желаемому.

\section{4. Ностальгические стратегии сознания эмигранта}

Несомненна пограничность сознания эмигранта как его отличительная черта. В этой связи актуален вопрос о наличии особого эмигрантского психотипа, задающего парадигму мировосприятия, поведения, жизненного и духовного выбора личности. А. Пятигорский рассматривает эмиграцию как один из вариантов общих миграционных процессов, являющихся условием «человеческого существова- 
ния и вместе с тем» проявлением «важнейших состояний человека» [14]. Помимо объективных факторов «миграционной установки» как феномена присущего человечеству в целом, ученый допускает «возможность существования и некоего особого "миграционного" психотипа, в котором психическая миграционная тенденция является особенно сильной» [14]. Опираясь на мысль ученого, сознание эмигранта в целом как человека и непосредственно как творческой личности представляется самобытным и наделенным неким психокомплексом пограничности.

Семиотический статус эмигранта по определению близок путешественнику, а потенциальная возможность ностальгирования открывает пути идеализации значимых объектов, временных континуумов или же хронотопов. Аналогичный сдвиг сознания, согласно нидерландскому мыслителю Ф. Анкерсмиту, присущ и феномену ностальгирования. Так «ностальгия глубоко связана с чувством смещения или самим процессом смещения» [2, с. 371], подразумевая замену реального времени и места, в которых находится ностальгик, идеализированным хронотопом. Ф. Анкерсмит утверждает, что «ностальгия отнимает у объекта ностальгического желания конкретное существование, которым он все еще обладал в контексте исторического опыта» [2, с. 374]. Данная ситуация способствует выпадению личности из исторического времени и включению в режим мифологизирования, что в свою очередь обусловливает «связь пасторального топоса Аркадии с ностальгией» [11, с. 171].

Такая замена реальности мифологизированными моделями мировосприятия актуализирует стремление ностальгика модифицировать ситуацию собственной психологической и экзистенциальной пограничности. По утверждению О. Демидовой, в периоды катаклизмов и нестабильности, к которым в качестве частного явления исследовательница относит и ситуацию эмиграции, «миф в значительной степени способствует самоидентификации индивида...» [7, с. 511]. Эмигрантская среда первой волны, весьма разнородная как в плане политической, так и художественной идеологии, создавала и модифицировала различные сверхтексты: петербургский, московский, уездный, берлинский, парижский, пражский и др. Эстетизации подвергался и «сам факт эмиграции, переживаемой не только в известных архетипических параметрах изгнания из Рая, но и в рамках посланничества» [7, с. 517]. 
В данном контексте следует оговорить, что для сегодняшних волн русской поэтической эмиграции позиция «посланничества» представляется неприемлемой в целом, не соответствуя духу времени, а также аксиологическим и этическим установкам современных поэтов. Мифологема же «потерянного Рая» по-прежнему остается в той или иной мере актуальной, может быть вытеснена, но неизменно взаимосвязана с режимом ностальгирования. Такой ракурс, в свою очередь, соответствует ментальным стратегиям и современной поэтической диаспоры: вниманию к урбанизации сознания человека, соотнесению его с городской средой, поиску модели идеализированного хронотопа, актуализации процессов идентификации и мифотворчества. Значимость для ностальгика вариаций сюжета «изгнания из Рая» высвечивает как потенциал пасторальных коннотаций, так и фантазийный модус ностальгического дискурса.

С точки зрения А. Гринштейна образ «Потерянного рая» образует смысловую парадигму, где «различные проявления этого метатопоса (Золотой век, Потерянный рай, Остров блаженных, Аркадия и т. д.) выступают в тексте как формы осуществления разных модальностей в рамках одного модуса...» [6, с. 161]. Для лирики А. Петровой в целом показательно стремление избегать прямого использования вышеназванного метатопоса. Если образ Аркадии и присутствует, то только в подтексте. Для поэтессы характерно обыгрывать скорее тему утраты, чем стремления вернуться в утраченный Эдем. По наблюдению Н. Пахсарьян, нынешнее время не пасторально по своему духу - это эпоха «путешественников, людей, не сидящих на месте и не замыкающихся в одном тесном пространстве дома» [11, с. 185]. В связи с таким ракурсом рассмотрения невозможна фиксация на одном идеализированном объекте, приравниваемом мифологической Аркадии.

Но допустим и принципиально иной взгляд на проблему актуализации сознанием идеи символического топоса утраченного счастья. Согласно утверждению современного немецкого философа П. Слотердайка, «эмиграция сегодня стала диагнозом, характеризующим массовую психологию. Целые слои населения уже давно в душе живут где угодно, только не в этой стране» [18, с. 205]. Мысль П. Слотердайка обнажает меланхолическую окрашенность современности, для которой эмиграция, пусть даже только воображаемая, видится своего рода 
выходом из социального, психологического и экзистенционального тупика. В связи с таким раскладом неоднозначным представляется режим функционирования сегодня мифологемы «Потерянный Рай». Так «Землей обетованной» для эмигранта предстает не только прежняя родина, но и активизируется обратная ситуация, когда вариантом обретения Нового Парадиза становится желание покинуть место своего сегодняшнего пребывания, оторвавшись от своих корней, пусть даже только в воображении.

При этом фактор ностальгирования в целом, как и включение поэтом-эмигрантом ностальгических мотивов и символов в свой лирический дискурс, становится индикатором значимости, даже латентной и до конца неосознанной, утраченных корней и ощущения невозможности новой укорененности.

Изменчивость и смутная загадочность мира, зыбкость ранее константных основ, ощущение надлома, пороговости существования с одной стороны и тайное стремление обрести некий утерянный рай, эквивалентами которого могут быть дом, память, мечта, визия, ностальгия - с другой, становятся своего рода координатами, центрирующими лирический сюжет А. Петровой:

По колдовскому острову брожу.

Случайно вынесло сюда четыре,

пять, иесть, я не помню, лет.

Я их перевожу со словарём, но кости букв ссыпаются в песок, дробясь в сатурновый неуловимый слог.

Чужсе солнце проведёт резцом мориины, тыл не узнаешь, кто это в воде, где тёмное лицуо женомужчины рябит, рассеиваясь в нигде.

Я заблудилась в середине лет, средь древних слов чешуйчато-крылатых средь лингвоклонов и химер. Лишь дальний голос словобрата 
в лесу косых лучей

мне приоткроет дверь.

Запутывваясь в ветвях, так медленно, по звуко-карте,

- косяк свободных птич - ко мне пробьются первые слова,

и те, что мальчик вырезал на парте

и заключил в ущербленный овал [12].

\section{5. Семиотический потенциал островной тематики}

Тема колдовского острова помимо имплицитного обыгрывания мифологических топосов и введения в текст стихотворения литературных аллюзий, подразумевает траекторию движения по кругу. Ю. М. Лотман отмечает, что «движение по кругу имеет колдовскую, магическую, - а с средневеково-христианской точки зрения, дьявольскую - природу...» [9, с. 309]. Лотмановские идеи, несомненно, значимы в ментальном универсуме Александры Петровой, окончившей филологический факультет Тартуского университета.

В семиотическом плане показательна круглая форма острова и его связь с миром волшебства, сознательно обыгрываемая А. Петровой. Закольцованность, символизируемая кругом и потенциями «островного сюжета», актуализирует тему вечного повторения, жизни как мифологического цикла и поиска себя в воспоминаниях о прошлом, становящихся гарантией заданности сложившейся судьбы, самоуглубления и неизбежности ностальгии.

Остров мифологически всегда представляет модель некоей инаковости, магичности и загадочности, с акцентом на амбивалентном сочетании открытости и закрытости. Именно поляризация и в то же время взаимодополнение открытости / закрытости моделируют различные «островные сюжеты». Одной из таких сюжетных схем является путешествие с подразумевающимися отдалением и приближением к острову как реально географическому, так и мифологико-метафорическому объекту.

Показательна мысль Т. Цивьян, что «литературный жанр путешествий был заложен путешествиями по морю, путешествиями на острова, и что образцом-клише, так сказать, “первопутешествием”, стало путешествие Одиссея» [26, с. 156]. Семиотическую модель 
острова определяет колдовской потенциал и связь со своеобразной путевой тематикой. Такой спектр пути в свою парадигму включает значения от «первопутешествия» Одиссея до поиска своей идентичности в осознании себя в мире, ментальных и гендерных кодах, воспоминаниях, онирической реальности. В лирическом сюжете стихотворения «По колдовскому острову брожу...» поэта-эмигранта Александры Петровой таким вариантом «островного сюжета» становятся как реминисценции из «Одиссеи», так и переживание ностальгии.

\section{6. Одиссей как «homo viator» и первый ностальгик}

Несомненно, тема ностальгии традиционно связана с образом Одиссея, первого ностальгика ${ }^{1}$, воплощающего тоску по родине, прошлому и в то же время обреченного на неизбежные странствия и противостояние судьбе.

По замечанию Ж. Старобинского, «начало поэтике ностальгии, оказавшей столь сильное влияние на западную интеллектуальную традицию, положили несколько великих эпических либо сакральных текстов. $<\ldots>$ В литературной памяти Античности состояние Улисса у Калипсо становится парадигматическим образом жизни на чужбине» [20, с. 272-273]. Данное наблюдение ученого акцентирует не только связь темы Одиссея с «островным сюжетом» и феноменом ностальгии, но и высвечивает роль нимфы Калипсо в обособлении героя от мира. Замкнутость в рамках существования эмигранта неизбежно пробуждает ощущение у ностальгика утраты возможности обретения новых сближений и новой родины.

Характерна и «эпистемологизация одиссеевского опыта путешественника как протомодели эмигранта» [22, с. 162]. Авторы статьи, показательно названной «Ноmo viator», что в переводе с латыни означает «Человек-путник», осмысляют культурологический статус путешествия, выявляя его семиотические коды. «“Путешествовать” означает, как минимум, “перемещаться в пространстве”. <..> Где перемещение в пространстве - там и пересечение границ. А это уже проблематика “образа Другого”: статус путешественника располагает и иногда даже вынуждает к вынесению суждений об увиденном»

\footnotetext{
${ }^{1}$ Термин веден в научный оборот Светланой Бойм.
} 
$[21$, с. 6]. Подобный рассказ соотносит различные типы повествования от фиксации реальных впечатлений и наблюдений до фантазирования. Фактор как экзистенциального, познавательного и символического опыта «homo viator», так и травелога - повествования «о различных реальных или вымышленных путешествиях в пространстве и времени» [16, с. 14] формируют основу для «субъективно-творческого освоения мира человеком» [16, с. 14], а в случае рецепции поэтом-эмигрантов активируют ностальгический дискурс.

Поведенческие стратегии во взаимоотношениях с миром «homo viator», прототипом которого, во многом, является Одиссей, могут соотносится не только непосредственно с путешественником, но и шире с образом эмигранта. Существует также точка зрения, согласно которой Одиссей «это человек границы, который своими путешествиями очерчивает границы греческой идентичности» [10, с. 39]. В данном плане примечательны статус «другого», нарушение границ и потребность рассказа о своих перемещениях, практическом и духовном опыте путешественника или же эмигранта - человека границы. Именно «путешествие запускает механизм рефлексии путешественника по поводу его собственной идентичности (в частности, национальной или цивилизационной / культурной)» [21, с. 6]. Вышеотмеченные нарративные практики и стремление к самоидентификации взаимосвязаны и потенциально обусловлены ностальгическим мировосприятием, определяя тяготение к исповедальному дискурсу как в очистительном, экзистенциальном, так и в познавательном и игровом планах.

\section{7. Одиссеев миф в ностальгическом дискурсе}

Аллюзия Одиссея на колдовском острове обыгрывается в анализируемом стихотворении А. Петровой как вариант не только ощущения тоски и одиночества, но и воплощения особой судьбы. По сути, А. Петрова в своем поэтическом тексте, видимо, сознательно контаминирует разные мифологические топосы, где во время своих странствий побывал Одиссей. Так Огигия узнается из перечисления количества лет, проведенным лирическим «я» на колдовском острове.

По колдовскому острову брожу.

Случайно вынесло сюда четыре, пять, шесть, я не помню, лет. 
Известно, что Одиссей находился в плену у Нимфы Калипсо семь лет. В то же время тема утраты памяти и сопротивления этому, отсылают к истории лотофагов, пьющих сок лотоса, дарующий забвение. Колдовским является и остров волшебницы Цирцеи, у которой также жил Одиссей. Показательно, что по наблюдению А. В. Подосонова, «начиная от лестригонов и до Сирен, маршрут плавания Одиссея совершенно невозможно начертить на современной карте» $[13$, с. 75$]$. Ученый фиксирует и факт дискуссии «о том, где находился остров Кирки Ээя (в Северно-Восточном океане или в Италии)» [13, с. 76]. Но учитывая факт эмиграции А. Петровой именно в Италию, представление о существовании италийского мыса Керкей, где хранится легендарная чаша Одиссея, можно расценивать как фактор адекватный авторскому мифу поэта-эмигранта.

О.А. Ханзен-Лёве отмечает двойничество Кирки (Цирцеи) и нимфы Калипсо. Одиссеевское пребывание на Ээе и Огигии мифологи расценивают как нахождение в Иномирье, а уход от Цирцеи и Калипсо - возвращение в мир живых. В лирическом тексте Александры Петровой ностальгия отождествляется с образом замкнутого пространства - колдовским островом, и персонифицируется в фигуре нимфы Калипсо, удерживающей в плену Одиссея.

Феномен ностальгирования и тема нифмы Калипсо, «той, что скрывает» и способна даровать бессмертие, по мысли О. А. Ханзена-Лёве, прочно взаимосвязанны. «Последнее свойство Калипсо также, как ее связь с ностальгией мифологического героя, идеально подходит к общей модели калиптической эстетики в творчестве таких авторов, как Набоков, Мандельштам, Бродский и др., живущих и пишущих под властью ностальгии и тоски по памяти культуры и утраченному времени» [23, с. 133]. Мысль австрийского литературоведа акцентирует в творчестве авторов-эмигрантов или же тех, кто по моральным причинам могут чувствовать себя изгнанниками, связь лирико-меланхолического настроя с ностальгированием и значимость для поэтики потаенного, того, что неизменно сокрыто в подтексте.

По мнению С. Бойм, возращение Одиссея на родину «это <...> ритуальное событие, которое не начинется и не заканчивается с ним» [3, с. 39]. Так миф об эмигранте потенциально отсылает к истории тоскующего Улисса, утрачивающего радость жизни и мысленно обращающегося к Итаке, практически не достижимой. 
Осмысляя фактор одиссеевской ностальгии С. Бойм, делает вывод, что «коварные колыбельные Цирцеи эхом отражаются в мелодиях дома» [3, с. 40]. Мифологическая составляющая феномена ностальгии оказывается примечательна не только страданием от невозможности возвращения и ощущением нахождения в замкнутом, заколдованном круге, но и тайным желанием этого возвращения избежать. Показательны предчувствия опасности, разочарований, а главное моральной недостижимости возращения домой, поскольку пространство ностальгии носит ментально-эмоциональный характер и делает призрачной реальную родину, которая к тому же за время отсутствия значительно изменилась. Ностальгик не только оказывается в амбивалентной ситуации противоречивых желаний возвращения / невозвращения, но и внутренне ориентирован на предпочтение мира воображаемого миру реальному, где бы не находился.

\section{8. Феномен двойничества в рамках ностальгического дискурса А. Петровой}

В стихотворении А. Петровой альтернативой ностальгического чувства и поиска своей идентичности становится авторский миф об обретении «словобрата» - альтер эго лирического «я».

Лишь дальний голос словобрата

в лесу косых лучей

мне приоткроет дверь.

Фактор введения в текст темы подобного двойничества активирует широкие возможности интерпретации. Образ «словобрата» представляет как слиянность, так и разделение единой личности на мужское и женское начало, что вполне согласуется с интенциями авторского мифа А. Петровой. Но не менее значима стратегия поиска двойника во вне авторской психосферы, в виде соотнесения с конкретными или, же воображаемыми персоналиями и ипостасями. По наблюдению С.3. Агранович и И.В. Саморуковой, близнечность принципиально отличается от двойничества. Так «двойники-антагонисты сначала сходны, а потом противоположны. Близнецы же сперва предстают как антагонисты, а в конце обнаруживается идентичность их позиций 
и участи» $[1$, с. 47]. Кроме того, исследователи, акцентируя фактор соотнесения в русской литературе близнецов с социальным низом, в качестве разновидности которого называют статус эмигранта. Фактор двойничества, проявляющийся в лирическом сюжете А. Петровой на уровне близнечности, в культурологическом плане соотносим с темой эмигрантов. Переживание ностальгии определяет раздвоенность сознания и стремление обрести целостность своей личности в моделируемом фантазией образе близнеца.

По наблюдениям Л. Бугаевой, «писатели-эмигранты и писатели-экспатрианты часто используют себя в качестве модели; авторефлексивное повествование отчасти выполняет роль зеркала, в котором субъектный взгляд автора активизирует воображение и память, в т. ч. память о непрожитом» [4, с. 203]. Включение ностальгического дискурса в лирический сюжет поэта-эмигранта, а возможно, и во всю лирическую систему, вполне закономерно позволяет активизироваться в процессе идентификации воображению. Взаимосвязь исповедальности и фантазийного модуса, способствуя самопознанию и своего рода духовному поиску, позволила исследователям дискурса травелога дать определение лирической поэзии - «травелог души» [16, с. 15]. Поэтическому тексту в еще большей степени, чем прозаическому, присуща активация фантазийной модальности при создании образа лирического «я» и выбора масок в соответствии с установками авторского мифа.

Стратегии отождествления взаимосвязаны с представлением о «зеркале» и поэтикой масок, определяющей, по слову Н.В. Сподарец, механизмы проявления «литературной идентификации “Я” в системе отношений с Другим, моделей перманентной трансгрессии» $[19$, с. 230]. А. Петрова создает ситуацию зеркальности, где двойником ее лирического «я» окажется иная сторона ее натуры. Такими мифологическими героями, в избранном для анализа стихотворении при первом его прочтении предстают Одиссей и потенциально нимфа Калипсо.

В соответствии с ментальным универсумом современной поэтессы при гендерной амбивалентности лирическое «я» может идентифицироваться как с самим Одиссеем, так и его возлюбленными - хозяйками волшебных островов, а также возможен вариант слиянности мужского и женского в одну личность «женомужчины». 
Чужсе солние проведёт резиом морщуинь, тыл не узнаешь, кто это в воде, где тёмное лицо женомужчинь рябит, рассеиваясь в нигде.

\section{9. Результаты анализа}

Стихотворение Александры Петровой интересно именно переосмыслением и трансформацией ностальгических доминант, как возведенных в ранг мифологем, так и уже успевших стать стереотипами. В лирическом дискурсе А. Петровой мифологические и литературные маски необходимы для идентификации. Изгнанничество лирического «я», в отличие от Одиссея, который вынужден жить в плену влюбленной в него нимфы Калипсо, хоть тоже мучительное, но добровольное. Видимо, согласно авторскому мифу А. Петровой страсть и самопознание не возможны без погруженности в свои воспоминания и мечты о несбыточном.

Мифологемы изгнания, меланхолии и духовной устремленности домой становятся не только знаковыми для одиссеева мифа, но и складываются в определенный мифопоэтический комплекс актуальный для сознания поэта-эмигранта, не забывающего свою родину и в то же время создающего ее фантазийную, идеализированную модель.

\section{0. Выводы}

В ходе исследования представлена попытка осмысления феномена ностальгии как культурно-эмоционального комплекса, обусловливающего специфику литературного сознания эмигранта. Выявлены архетипические составляющие ностальгии и предполагаемая парадигма поведения и мировосприятия ностальгика. Поставлен вопрос о преемственности в семиотическом плане статусов путешественника и эмигранта, переживающих ностальгию. Проанализированы факторы влияния ностальгических идеологем на творческую деятельность поэтов-эмигрантов. Осмыслена пороговость сознания, отличающая психосферу эмигранта, чей семиотический статус близок путешественнику. Акцентирована взаимообусловленность ностальгии и меланхолии. Прояснена функция кодов «семиотики страстей» в ностальгическом дискурсе. Прослежены проявления феномена ностальгии в знаковом лирическом сюжете современного поэта-эми- 
гранта Александры Петровой. Обозначены художественные приоритеты творческого мышления А. Петровой как поэта-эмигранта и засвидетельствована трансгрессивная специфика ее поэтического сознания. Продемонстрирована алюзийная специфика стихотворения «По колдовскому острову брожу...». Обосновано влияние на авторский миф А. Петровой места ее эмиграции - Италии. Проанализирована специфика одиссеева мифа, его связь с «островным сюжетом», с поведенческими стратегиями «homo viator» и калиптической поэтикой. Акцентирована роль мифологических, семиотических и гендерных кодов в моделировании лирического сюжета, а также процессе идентификации лирического «я». Осмыслены факторы проявления исповедальности и двойничества в акте переживания ностальгии. Двойничество в авторском мифе А. Петровой проявляется разнонаправлено. В виде взаимозамены феменинных и маскулинных кодов в обыгрывании пограничности сознания. Показательна трансформация близнечного мифа как обретение альтер «эго» - «словобрата». Представляет интерес активация поэтики масок в поэтическом дискурсе А. Петровой. Выявлены значимые литературные маски (Одиссей, Калипсо, Цирцея) в акте идентификации лирического «я».

Осмысление лирического сюжета А. Петровой позволило интерпретировать стратегии мифологизации ностальгического дискурса. Выявлена вариативность, присущая идеализированным объектам и хронотопам, входящим в смысловое поле, моделируемое фантазией ностальгика. Прослежены механизмы манифестируемого отказа от поиска идентичности и в то же время стратегии идентификации, присущие поэтической манере А. Петровой. Сделан вывод о высокой степени архетипичности образной системы А. Петровой, что обусловлено как экзистенциальной модальностью переходной эпохи, так и установками авторского мифа поэтессы.

Перспективным представляется дальнейшее исследование феномена ностальгии в лирическом дискурсе поэтов-эмигрантов.

\section{Список литературы:}

1. Агронович С.3., Саморукова И.В. Двойничество. Самара : Самарский университет, 2001. $132 \mathrm{c}$.

2. Анкерсмит Ф.Р. История и тропология: взлет и падение метафоры. Москва : Пресс-Традиция, 2003. 496 с. 
3. Бойм С. Будущее ностальгии. Москва : НЛО, 2019. 680 с.

4. Бугаева Л.Д. Литература и rite de passage. Санкт-Петербург : Петрополис, 2010. $408 \mathrm{c}$.

5. Греймас А.Ж., Фонтаний Ж. Семиотика страстей. От состояния вещей к состоянию души. Москва : ЛКИ, 2007. 336 с.

6. Гринштейн А.Л. Потерять нельзя найти: пасторальная и идиллическая топика в романе П. Акройда «Мильтон в Америке» Многоликая пастораль: современные проблемы изучения. Москва : Академия им. Моймонида, 2018. С. 161-170.

7. Демидова О.Р. Эстетизация как стратегия мифотворчества: эмигрантский вариант. Миф и художественное сознание XX века. Москва : КанонПлюс, 2011. С. 511-533.

8. Линькова Я.С. Научные трактовки метажанра пасторали 2000-х годов Человек: образ и сущность. 2011. Вып. 1(22): Современный человек: Движение к пасторали? С. 263-273.

9. Лотман Ю.М. Внутри мыслящих миров. Семиосфера. Санкт-Петербург : Искусство - СПБ, 2004. С. 150-390.

10. Обидина Ю.С. Представления о загробном мире в контексте коллективной памяти древних греков: опыт Одиссея как человека «границы». Вестник марийского государственного университета. 2015. Т. 1. Вып. 1. С. 38-42.

11. Пахсарьян Н.Т. Пасторальное отшельничество как выбор современного парижанина: роман Ж.-М. Шеврье «Далекая Аркадия» Человек: образ и сущность. 2011. Вып. 1 (22): Современный человек: Движение к пасторали? С. 170-187.

12. Петрова А. Только деревья. Москва : НЛО, 2007. 120 с.

13. Подосинов А.В. Куда плавал Одиссей? Аристей. 2012. Вып. 5. C. $72-113$.

14. Пятигорский А. Миграция. Диффузия. Антропоток. Сообщение. 2003. Вып. 2. : Антропотоки: Концепт. URL: http://soob.ru/n/2003/2/concept/5

15. Рикёр П. Я-сам как другой. Москва: Изд-во гуманитарной литературы, 2008. $416 \mathrm{c}$.

16. Русаков В.М., Русакова О.Ф. Методология дискурс-исследования травелога. Дискурс Пи. Т. 4. Вып. 11. 2014. С. 14-20.

17. Сандлер С. Поэт как перемещенное лицо: предисловие. Только деревья. Москва : НЛО, 2007. С. 5-12.

18. Слотердайк П. Критика цинического разума. Екатеринбург : У-Фактория, 2009. 800 с.

19. Сподарец Н.В. Модернизм Серебряного века: литературоведческая идентификация. Одесса : Астропринт, 2017. 452 с.

20. Старобинский Ж. Чернила меланхолии. Москва : НЛО, 2016. 616 с.

21. Толстиков А.В., Кошелева О.Е. Ното viator Одиссей : Человек в истории : Путешествие как историко-культурный феномен. Москва : Наука, 2010. C. 5-11.

22. Фокина С.А. Ностальгия в авторском мифе поэта-эмигранта Александры Петровой. Вчені записки таврійського начіонального універ- 
ситету імені B.I. Вернадського. Серія: Філологія. Соціальні комунікації. T. 30(69). № 42019. Ч. 1. 2019. С. 161-166.

23. Ханзен-Лёве О.А. Интермедиальность в русской культуре: От символизма к авангарду. Москва : РГГУ, 2016. 450 с.

24. Хренов Н.А. Культура в эпоху социального хаоса. Москва : Едиториал УРCC, 2002. $448 \mathrm{c}$.

25. Цветаева М. Собрание сочинений: в 7 т. Москва : ТЕРРА. 1997. Т. 5. Кн. 2 : Статьи; Эссе; Переводы. 400 с.

26. Цивьян Т. Остров, островное сознание, островной сюжет. Языл : тема и вариации: избранное: в 2 кн. Кн. 2. : Античность. Язык. Знак. Миф и фольклор. Поэтика. Москва : Наука, 2008. С. 151-160.

27. Шевеленко И. Литературный путь Цветаевой: Идеология - поэтика идентичность автора в контексте эпохи. Москва : НЛО, 2002. 464 с.

28. Юханнисон К. История Меланхолии. О страхе, скуке и печали в прежние времена и теперь. Москва : НЛО, 2011. 320 с.

\section{References:}

1. Agronovich S.Z., Samorukova I.V. (2001). Dvojnichestvo. [Dual]. Samara: Samara University. (in Russian)

2. Ankersmit F.R. (2003). Istorija $i$ tropologija: vzlet $i$ padenie metafory [History and triology: the rise and fall of the metaphor]. Moscow: Press Tradition. (in Russian)

3. Bojm S. (2019). Budushhee nostal'gii [The future of nostalgia]. Moscow: NLO. (in Russian)

4. Bugaeva L.D. (2010). Literatura $i$ rite de passage [Literature and rite de passage]. St. Petersburg: Petropolis. (in Russian)

5. Grejmas A.Zh., Fontanij Zh. (2007). Semiotika strastej. Ot sostojanija veshhej $k$ sostojaniju dushi [Semiotics of passions. From the state of things to the state of the soul]. Moscow: LKI. (in Russian)

6. Grinshtejn A.L. (2018). Poterjat' nel'zja najti: pastoral'naja i idillicheskaja topika v romane P. Akrojda [The Loss Cannot Be Found: The Pastoral and Idyllic Topics in P. Ackroyd 's novel «Milton in America»] Mnogolikaja pastoral': sovremennye problemy izuchenija [The Multi-Faceted Pastorale: Modern Problems of Study]. Moscow: Moimonid Academy, pp. 161-170.

7. Demidova O.R. (2011). Jestetizacija kak strategija mifotvorchestva: jemigrantskij variant. [Aesthetics as a strategy of mythology: an emigrant version] Mif $i$ hudozhestvennoe soznanie XX veka [Myth and artistic consciousness of the 20th century]. Moscow: Kanon-Plus, pp. 511-533.

8. Lin'kova Ja.S. (2011). Nauchnye traktovki metazhanra pastorali 2000-h godov. Chelovek: obraz i sushhnost' [Scientific interpretations of the pastoly of the 2000s Man: image and essence] Modern man: The movement to pastoralism? no. 1(22), pp. 263-273.

9. Lotman Ju. M. (2004). Vnutri mysljashhih mirov [Inside the thinking worlds] Semiosfera [Semiosphere]. St. Petersburg: Iskusstvo - SPB, pp. 150-390. 
10. Obidina Ju.S. (2015). Predstavlenija o zagrobnom mire v kontekste kollektivnoj pamjati drevnih grekov: opyt Odisseja kak cheloveka «granicy» [Perceptions of the Afterworld in the Context of the Collective Memory of Ancient Greeks: Odyssey's Experience as a Man of the "Frontier"]. Mari State University Gazette, vol. 1, no. 1, pp. 38-42.

11. Pahsar'jan N.T. (2011). Pastoral'noe otshel'nichestvo kak vybor sovremennogo parizhanina: roman Zh.-M. Shevr'e «Dalekaja Arkadija» [Pastoral Hermit as a Choice of Modern Parisian: Novel by J.-M. Chevrier "The Distant Arcadia"]. Man: Image and Essence, no. 1(22): Modern man: The movement to pastoralism?

12. Petrova A. (2007). Tol'ko derev'ja [Only trees]. Moscow: NLO. (in Russian)

13. Podosinov A. V. (2012) Kuda plaval Odissej? [Where did Odysseus swim?]. Aristaeus, no. 5, pp. 72-113.

14. Pjatigorskij A. (2003). Migracija. Diffuzija. Antropotok [Migration. Diffusion. Anthropocurrent] So-obshhenie (electronic journal), no. 2. Anthropocurrents: Concept. Retrieved from: http://soob.ru/n/2003/2/concept/5

15. Rikjor P. (2008). Ja-sam kak drugoj [I-myself as another]. Moscow: Ministry of Humanitarian Literature. (in Russian)

16. Rusakov V.M., Rusakova O.F. (2014). Metodologija diskurs-issledovanija traveloga [Methodology of discourse-research of travelog]. Pi's discourse, vol. 4, no. 11, pp. 14-20.

17. Sandler S. (2007). Pojet kak peremeshhennoe lico: predislovie [Poet as Displaced Person: Foreword]. Tol'ko derev'ja [Only trees]. Moscow: NLO, pp. 5-12.

18. Sloterdajk P. (2009). Kritika cinicheskogo razuma [Criticism of the Cynical Mind]. Yekaterinburg: U-Faktorija. (in Russian)

19. Spodarec N.V. (2017). Modernizm Serebrjanogo veka: literaturovedcheskaja identifikacija [Modernism of the Silver Age: literary identification]. Odessa: Astroprint. (in Russian)

20. Starobinskij Zh. (2016). Chernila melanholii [Melancholy ink]. Moscow: NLO. (in Russian)

21. Tolstikov A.V., Kosheleva O.E. (2010). Homo viator. Odissej: Chelovek v istorii : Puteshestvie kak istoriko-kul'turnyj fenomen [Odysseus: Man in History: Journey as a Historical and Cultural Phenomenon]. Moscow: Nauka, pp. 5-11.

22. Fokina S.A. (2019). Nostal'gija $v$ avtorskom mife pojeta-jemigranta Aleksandry Petrovoj [Nostalgia in the author's myth by the poet emigrant Aleksandra Petrova] Scientists of notes of Tavrichesky National University named after V.I. Vernadsky. Series: Philology. Social komknikation. vol. 30(69). № 42019. P. 1, pp. 161-166.

23. Hanzen-Ljove O.A. (2016). Intermedial'nost'v russkoj kul'ture: Ot simvolizma $k$ avangardu [Intermediality in Russian culture: From symbolism to avantgarde]. Moscow: RGGU. (in Russian)

24. Hrenov N.A. (2002). Kul'tura v jepohu social'nogo haosa [Culture during an era of social chaos]. Moscow: Editorial URSS. (in Russian)

25. Cvetaeva M. (1997). Sobranie sochinenij: $v 7$ t. T. 5. Kn. 2.: Stat'i; Jesse; Perevody [Collection of works in 7 vol. Vol. 5. P. 2: Articles; Essay; Translations] Moscow: TERRA. (in Russian) 
26. Civ'jan T. (2008). Ostrov, ostrovnoe soznanie, ostrovnoj sjuzhet [Island, island consciousness, island plot] Jazyk: tema i variacii: izbrannoe: $v 2$ kn. Kn. 2: Antichnost'. Jazyk. Znak. Mif i fol'klor. Pojetika [Language: theme and variations: favorites: in 2 vol. Vol. 2: Antiquity. Language. Sign. Myth and folklore. Poetics]. Moscow: Nauka. (in Russian)

27. Shevelenko I. (2002). Literaturnyj put' Cvetaevoj: Ideologija - pojetika - identichnost' avtora $\mathrm{v}$ kontekste jepohi [The Literary Way of Tsvetayeva: Ideology - Poetry - Identity of the author in the context of the era]. Moscow: NLO. (in Russian)

28. Johannisson K. (2011). Istorija Melanholii. O strahe, skuke i pechaliv prezhnie vremena i teper' [Melancholy history. Fear, boredom and sadness in old times and now]. Moscow: NLO. (in Russian) 